\title{
Sulindac sulfide inhibits colon cancer cell growth and downregulates specificity protein transcription factors
}

\author{
Xi Li', Satya S. Pathi ${ }^{2}$ and Stephen Safe ${ }^{1 *}$
}

\begin{abstract}
Background: Specificity protein (Sp) transcription factors play pivotal roles in maintaining the phenotypes of many cancers. We hypothesized that the antineoplastic effects of sulindac and its metabolites were due, in part, to targeting downregulation of Sp transcription factors.

Methods: The functional effects of sulindac, sulindac sulfone and sulindac sulfide on colon cancer cell proliferation were determined by cell counting. Effects of these compounds on expression of Sp1, Sp3, Sp4 and pro-oncogenic Sp-regulated genes were determined by western blot analysis of whole cell lysates and in transient transfection assays using GC-rich constructs.

Results: Sulindac and its metabolites inhibited RKO and SW480 colon cancer cell growth and the order of growth inhibitory potency was sulindac sulfide > > sulindac sulfone > sulindac. Treatment of SW480 and RKO cells with sulindac sulfide downregulated expression of Sp1, Sp3 and Sp4 proteins. Sulindac sulfide also decreased expression of several Sp-regulated genes that are critical for cancer cell survival, proliferation and angiogenesis and these include survivin, bcl-2, epidermal growth factor receptor (EGFR), cyclin D1, p65 subunit of NFKB and vascular endothelial growth factor (VEGF). Sulindac sulfide also induced reactive oxygen species (ROS) and decreased the level of microRNA-27a in colon cancer cells, which resulted in the upregulation of the Sp-repressor ZBTB10 and this resulted in downregulation of Sp proteins.
\end{abstract}

Conclusions: The results suggest that the cancer chemotherapeutic effects of sulindac in colon cancer cells are due, in part, to its metabolite sulindac sulfide which downregulates Sp transcription factors and Sp-regulated pro-oncogenic gene products.

Keywords: Sulindac sulfide, Sp transcription factors

\section{Background}

Nonsteroidal anti-inflammatory drugs (NSAIDs) and cyclooxygenase (COX) inhibitors are widely used as analgesics and treatment of diseases associated with an inflammatory response, such as arthritis and cardiovascular diseases. Cancer has been associated with inflammation and there is epidemiologic evidence that NSAIDs decrease the risk for development of several cancers [1-3]. Several studies show that the use of aspirin and other NSAIDs is associated with decreased

\footnotetext{
*Correspondence: ssafe@crm.tamu.edu

'Department of Veterinary Physiology \& Pharmacology, Texas A\&M

University, College Station, TX 77843-4466, USA

Full list of author information is available at the end of the article
}

incidence of colon cancer, and aspirin use and treatment is also associated with a decrease in colon polyp formation [4-6]. Aspirin and NSAIDs such as sulindac decrease colon polyp formation and the latter compound has been used in several clinical studies for inhibition of polyp formation in colon cancer patients and genetically susceptible individuals [7-9].

Sulindac, a COX-1 and COX-2 inhibitor, has been extensively investigated as a potent chemotherapeutic drug for treatment of colon and other cancers; however, due to the metabolism of sulindac (sulfoxide) to its sulfone (oxidation) or sulfide (reduction) metabolites, the mechanisms of action and identity of the active compound(s) are uncertain. Several reports show that sulindac and its 
metabolites exhibit pronounced pro-apoptotic activity in cancer cell lines and animal models and this includes activation of both extrinsic and intrinsic apoptosis pathways [10-17]. For example, sulindac induced apoptosis in HT-29 colon cancer cells and this is related to downregulation of survivin which in turn is due to decreased expression of $\beta$-catenin which regulates survivin expression through the transcription factor TCF-4 [13]. Other studies also show downregulation of $\beta$-catenin and/or survivin in cancer cells and tumors treated with sulindac or its metabolites [15-17] and the pro-apoptotic effect of survivin downregulation in head and neck sarcoma and carcinoma cells is STAT2-dependent $[11,12]$.

In addition, it has also been reported that sulindac and its metabolites exhibit growth inhibitory activity and this is associated, in part, not only with downregulation of survivin but also decreased expression of the epidermal growth factor receptor (EGFR) and vascular endothelial growth factor (VEGF) [18-21]. Studies in this laboratory have demonstrated that basal expression of genes, such as survivin, VEGF and EGFR, in various cancer cell lines is dependent on specificity protein (Sp) transcription factors Sp1, Sp3 and Sp4 [22-26] which are highly expressed in many cancer cells and tumors [27]. In this study, we initially compared the growth inhibitory effects of sulindac and its metabolites in SW480 and RKO colon cancer cells and their order of activity was sulindac sulfide $>$ sulindac sulfone $>$ sulindac after treatment for 24, 48 or $72 \mathrm{~h}$. At concentrations of sulindac and its metabolites that inhibited cell growth, we observed that only sulindac sulfide decreased levels of Sp1, Sp3 and $\mathrm{Sp} 4$ proteins and this was accompanied by decreased expression of Sp1-dependent genes such as VEGF, survivin, EGFR and bcl-2. Mechanistic studies suggest that sulindac sulfide induces reactive oxygen species (ROS) which in turn downregulates expression of Sp1, Sp3 and Sp4 in colon cancer cells [27].

\section{Methods}

Cell lines and cell culture, chemicals, oligonucleotides, plasmids and antibodies

SW480 and RKO colon cancer cell lines were obtained from the American Type Culture Collection (ATCC, Manassas, VA) and maintained in Dulbecco's modified Eagle's medium (DMEM) nutrient mixture with Ham's F-12 (DMEM/Ham's F-12) (Sigma-Aldrich, St. Louis, MO) as described [25]. Sulindac, sulindac sulfone and sulindac sulfide were purchased from LKT Laboratories (St. Paul, MN). Real-time PCR primer sequences for ZBTB10 are forward: 5'-GCT GGA TAG TAG TTA TGT TGC and reverse: 5'-CTG AGT GGT TTG ATG GAC AGA.

Sp1 construct (pSp1-Luc) contains the -751 to $-20 \mathrm{bp}$ promoter insert linked to a luciferase reporter gene [28] and Sp3 construct (pSp3-Luc) contains the -417 to -38 bp promoter insert [29]. Survivin construct (pSurvivin-Luc) contains the -220 to +49 bp promoter insert [30] and VEGF construct (pVEGF-Luc) contains the -2018 to +50 bp promoter insert [31] and miR-27a construct (pmiR-27a-Luc) contains the -603 to +36 bp promoter insert [32]. The empty luciferase vector pGL2 was also used in parallel as a negative control in luciferase assay. Sp1, survivin, cleaved PARP and $\beta$-actin antibodies were purchased from Upstate/Millipore (Lake Placid, NY), R\&D Systems (Minneapolis, MN), Cell Signaling Technology (Beverly, MA) and Sigma-Aldrich, respectively. Sp3, Sp4, EGFR, p65 and VEGF antibodies were purchased from Santa Cruz Biotechnology (Santa Cruz, CA).

\section{Cell proliferation assay}

Cells were plated in 12 -well plates $\left(3 \times 10^{4}\right.$ per well $)$ and allowed to attach for $24 \mathrm{~h}$. Cells were then treated with solvent control (DMSO) or varying concentrations of compounds and then trypsinized and counted after 24, 48 and 72 h using a Coulter Z1 particle counter.

\section{Western blot analysis}

Cells were plated in 6 -well plates $\left(3 \times 10^{5}\right.$ per well $)$, allowed to attach for $24 \mathrm{~h}$, and then treated with DMSO or varying concentrations of indicated compounds. Cells were lysed after 24 and $48 \mathrm{~h}$ and whole cell lysates were resolved on 7.5 or $12 \%$ SDS-PAGE gels and proteins were transferred onto polyvinylidene difluoride membranes by wet electroblotting. Membranes were probed for indicated proteins by antibodies and $\beta$-actin was used as a loading control.

\section{Flow cytometry}

Cells were treated with $100 \mu \mathrm{M}$ sulindac sulfide for indicated time and the general oxidative stress indicator CM- $\mathrm{H}_{2}$ DCFDA (Invitrogen/Life Technologies, Waltham, MA) was used according to the manufacturer's protocol. Fluorescence was measured by BD Accuri C6 flow cytometer (BD Biosciences, San Jose, CA) and data were analyzed according to the manufacturer's guide.

\section{Transfection and luciferase assay}

Cells were plated in 12 -well plates $\left(1.5 \times 10^{5}\right.$ per well), allowed to attach for $24 \mathrm{~h}$, and $400 \mathrm{ng}$ of luciferase construct (pSp1, pSp3, pSurvivin, pVEGF or pMir27a-Luc) and $40 \mathrm{ng}$ of $\beta$-galactosidase constructs $(\beta$-gal) with a constitutively active promoter were cotransfected into each well by Lipofectamine 2000 reagent (Invitrogen) and analyzed essentially as described [26].

\section{Quantitative real-time PCR and TaqMan assay}

Cells were treated as indicated and total RNA was extracted using RNeasy kit (Qiagen, Valencia, CA) then 
reverse transcribed using SuperScript reverse transcriptase (Invitrogen). Real-time PCR was carried out using a SYBR Green method (Applied Biosystems, Foster City, CA), and messenger RNA (mRNA) levels of target genes were normalized to that of the TATAbinding protein (TBP, as internal control). Total miRNA was extracted using mirVana isolation kit (Ambion/Life Technologies, Grand Island, NY) and TaqMan probes for miR-27a were purchased from the same company. TaqMan assay and analysis were carried out according to the manufacturer's protocol.

\section{Statistical analysis}

Statistical significance of differences between experiment groups in cell proliferation, luciferase, flow cytometry, real-time PCR and TaqMan assays was analyzed using unpaired Student's $t$-test and $P$ value of $<0.05$ was considered statistically significant. Experiments were done in triplicate and all results are expressed as mean \pm standard deviation (S.D.) for at least three independent determinations for each group.

\section{Results}

Results illustrated in Fig. 1a and b show that sulindac and sulindac sulfone inhibited growth of SW480 and RKO cells at cytostatic concentrations between 600-900 and 225-300 $\mu \mathrm{M}$, respectively. Western blot analysis of whole cell lysates from these cells indicated that 600 to $1200 \mu \mathrm{M}$ concentrations of sulindac did not affect expression of Sp1, Sp3 and Sp4 proteins in SW480 and RKO cells after treatment for 24 and 48 h (Fig. 1c). Similar results were observed in these cells after treatment with 225 or $300 \mu \mathrm{M}$ sulindac sulfone for 24 and $48 \mathrm{~h}$ (Fig. 1d) suggesting that growth inhibitory effects of these compounds was Sp-independent. Treatment of SW480 and RKO cells with 50 or $75 \mu \mathrm{M}$ sulindac sulfide for $24 \mathrm{~h}$ inhibited cell proliferation (Fig. $2 \mathrm{a}$ and b) and also slightly decreased expression of Sp1, Sp3 and Sp4 proteins in SW480 and RKO cells (Fig. 2c and d). Sulindac sulfide induced similar responses after treatment for $48 \mathrm{~h}$; however, at this time point, there was a pronounced downregulation of Sp1, Sp3 and Sp4 proteins in SW480 (Fig. 2c) and RKO (Fig. 2d) cells. Thus, sulindac sulfide was the most active sulindac derivative as observed in previous studies [33, 34] and the results suggest that the growth inhibitory effects of sulindac sulfide are correlated with downregulation of pro-oncogenic Sp proteins, and previous studies show that knockdown of one or more $[35,36]$ Sp proteins in colon cancer cells decreases cell cycle progression and induces apoptosis.

We also investigated the effects of sulindac sulfide on Sp-dependent pro-apoptotic, growth inhibitory and anti-angiogenic responses in colon cancer cells. Results illustrated in Figs. 3a and b show that sulindac sulfide decreased EGFR expression in SW480 and RKO cells after treatment for 24 and $48 \mathrm{~h}$ and this is consistent with a decrease of EGFR mRNA (qPCR data not shown). We also examined the effects of sulindac sulfide on the p65 subunit of NFkB which is an Sp-dependent gene product in some cancer cell lines $[26,35,37]$ and sulindac sulfide also decreased p65 expression in SW480 and RKO cells (Figs. 3a and b). In addition, sulindac sulfide also decreased expression of $\mathrm{NFKB}$ subunit p105 and upregulated expression of the $\mathrm{NF} \kappa \mathrm{B}$ inhibitor I $\mathrm{KB} \alpha$ in SW480 and RKO cells (qPCR data not shown). Thus, sulindac sulfideinduced inhibition of SW480 and RKO cell proliferation was accompanied by downregulation of Sp1, Sp3, Sp4 and the Sp-dependent gene products, EGFR and p65. Treatment of SW480 cells with sulindac sulfide also decreased survivin expression and this was accompanied by caspasedependent PARP cleavage which was observed after treatment for 24 and $48 \mathrm{~h}$ (Fig. 3c). Similar results were observed in RKO cells (Fig. 3d) and western blot data are in agreement with decrease of survivin transcript observed by qPCR (data not shown). It should be pointed out that the pro-apoptotic concentrations of sulindac sulfide were $25-50 \mu \mathrm{M}$ in both cell lines with effective concentrations decreasing with increasing treatment times which is similar to that observed for sulindac sulfide-dependent downregulation of Sp1, Sp3 and Sp4. In addition, sulindac sulfide also decreased expression of the Sp-dependent angiogenic VEGF gene product in SW480 (Fig. 3c) and RKO (Fig. 3d) cells, demonstrating that sulindac sulfidedependent downregulation of Sp1, Sp3 and Sp4 is accompanied by decreased expression of Sp-dependent growth promoting (EGFR), inflammatory (p65), survival (survivin) and angiogenic (VEGF) gene products. We also observed that knockdown of $\mathrm{Sp} 1$ by RNA interference inhibited RKO and SW480 cell growth by $>60 \%$ (data not shown) and this was consistent with previous reports showing that knockdown of Sp1 in these same cell lines resulted in a G0/G1 block in the cell cycle progression [36].

We also examined the effects of sulindac sulfide on luciferase activity in cells transfected with reporter constructs containing GC-rich sequences from the Sp1 (pSp1-Luc) and Sp3 (pSp3-Luc) gene promoters $[28,29]$. Sulindac sulfide decreased luciferase activity in both cell lines (Fig. 4a). Similar results were observed in cells transfected with the GC-rich survivin (pSurvivin-Luc) and VEGF (pVEGF-Luc) promoterluciferase constructs [30, 31] (Fig. 4b), demonstrating that sulindac sulfide also decreased expression of Sp-regulated genes with GC-rich promoters. These results suggest a mechanism that involves transcriptional repression of GC-box-driven genes through sulindac sulfide-induced Sp downregulation.

Several compounds including betulinic acid, tolfenamic acid and curcumin induce proteasome-dependent 


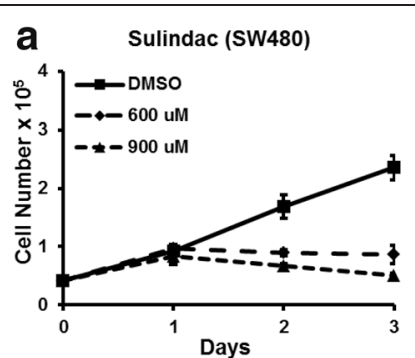

b Sulindac Sulfone (SW480)

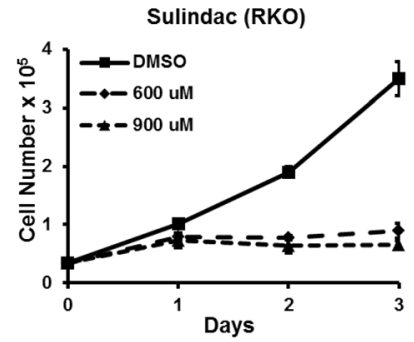

Sulindac Sulfone (RKO)
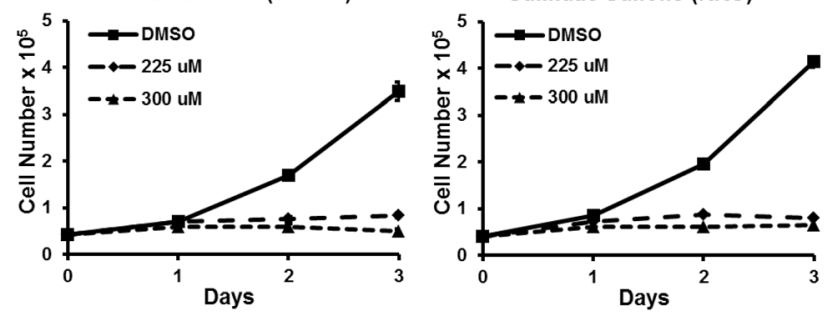

C


d

SW480
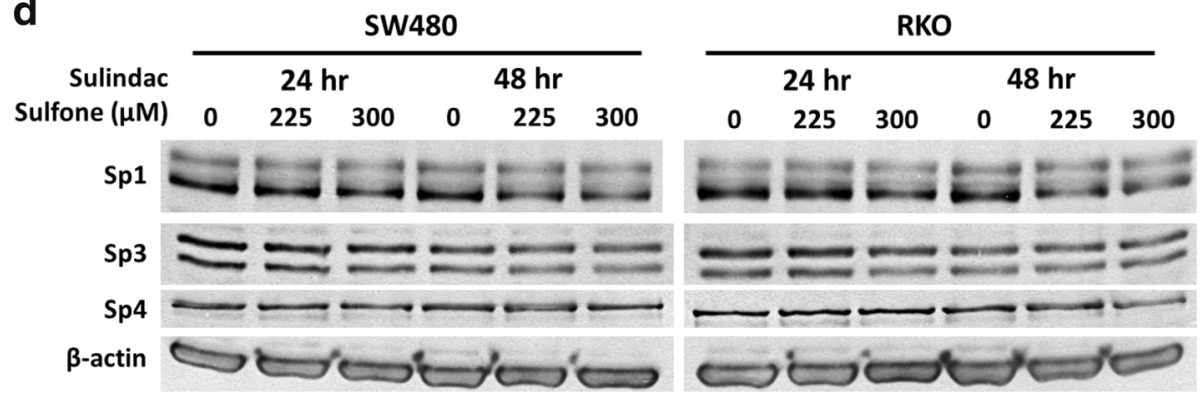

Fig. 1 Sulindac and sulindac sulfone inhibit colon cancer cell growth without decreasing expression of Sp1, Sp3 and Sp4 proteins. a, b Sulindac and sulindac sulfone inhibit SW480 and RKO cell proliferation. Cells were treated with solvent control (DMSO), 600 or $900 \mu \mathrm{M}$ sulindac, or 225 or $300 \mu \mathrm{M}$ sulindac sulfone for 24, 48 and $72 \mathrm{~h}$. Cell numbers were determined as described under Materials and Methods. Experiments were done in triplicate and results are expressed as mean \pm S.D. for each determination. $\mathbf{c}$, $\mathbf{d}$ Sulindac and sulindac sulfone have no effect on expression of Sp proteins in SW480 and RKO cells. Cells were treated with DMSO, 600 or $1200 \mu \mathrm{M}$ sulindac, or 225 or $300 \mu \mathrm{M}$ sulindac sulfone for 24 and $48 \mathrm{~h}$. Sp1, Sp3 and Sp4 cellular levels were determined by Western blot analysis as described under Materials and Methods and $\beta$-actin was used as loading control

degradation of $\mathrm{Sp}$ proteins in prostate, pancreatic and bladder cancer cells respectively [22, 23, 38, 39]; however, proteasome inhibitors did not block downregulation of Sp1, Sp3 or Sp4 by sulindac sulfide in SW480 and RKO cells (data not shown). Recent studies have identified a role for ROS in mediating repression of $\mathrm{Sp}$ proteins and the nitro-NSAID GT-094 and curcumin induce ROS-dependent downregulation of Sp proteins and Sp-regulated gene products in colon cancer cells
$[25,40]$. Results illustrated in Fig. 5 a show by flow cytometry that sulindac sulfide induced a time-dependent increase in ROS in SW480 and RKO cells. Figure 5b shows that sulindac sulfide downregulated Sp1, Sp3 and Sp4 proteins and this was partially reversed in SW480 cells cotreated with sulindac sulfide plus the antioxidant dithiothreitol (DTT). The other thiol antioxidants glutathione (GSH) and N-acetylcysteine (NAC) were less active than DTT as inhibitors of Sp downregulation in SW480 


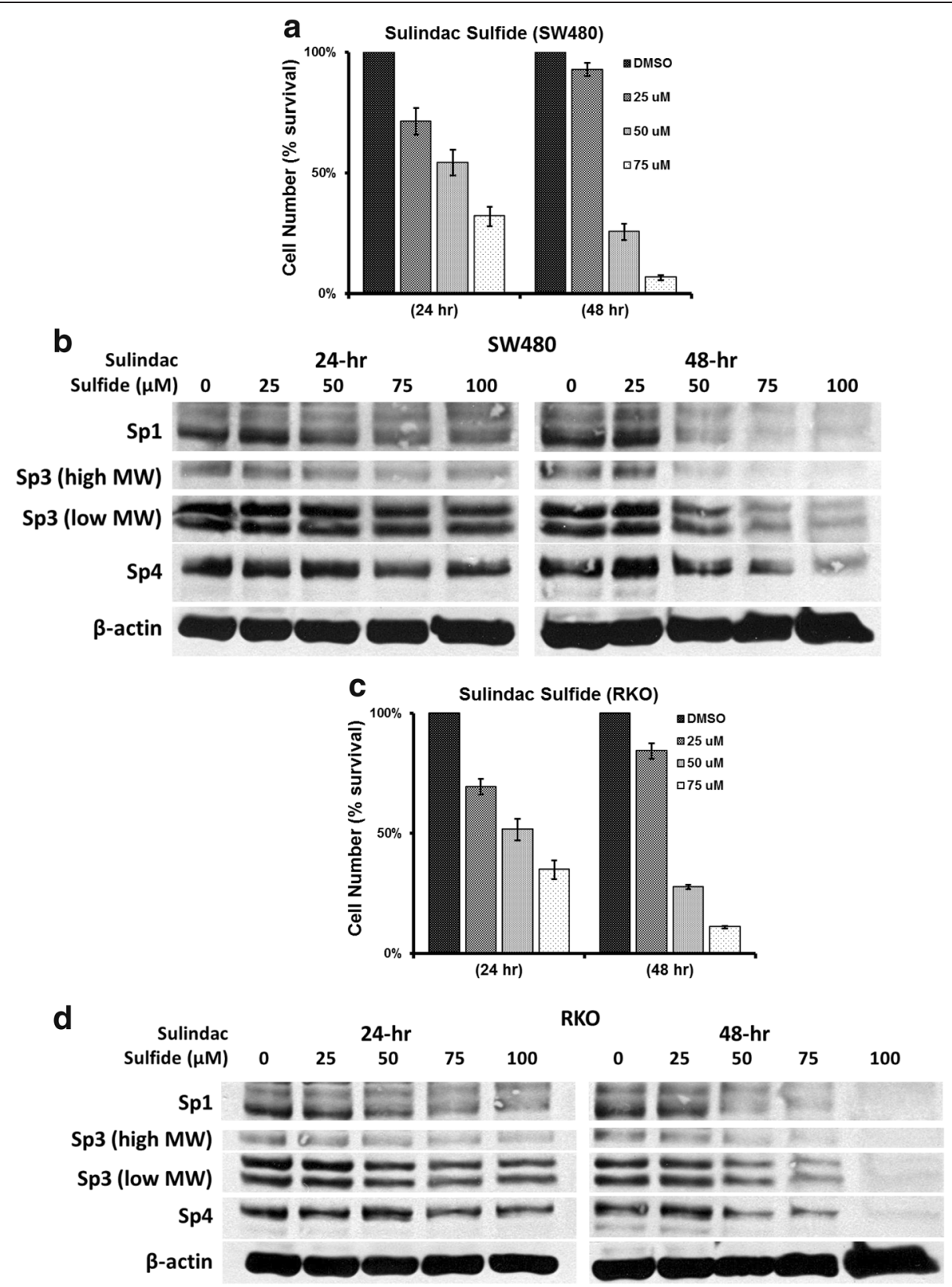

Fig. 2 Sulindac sulfide inhibits colon cancer cell growth and decreases expression of Sp1, Sp3 and Sp4 proteins. a, c Sulindac sulfide inhibits SW480 and RKO cell proliferation. Cells were treated with DMSO, 25, 50, and $75 \mu \mathrm{M}$ sulindac sulfide for 24 and $48 \mathrm{~h}$. Cell numbers were determined as described under Materials and Methods. Experiments were done in triplicate and results are expressed as percentage of control (mean \pm S.D.). b, d Sulindac sulfide decreases expression of Sp1, Sp3 and Sp4 proteins in SW480 and RKO cells. Cells were treated with DMSO, 25, 50, 75 and 100 MM sulindac sulfide for 24 and 48 h. Sp1, Sp3 and Sp4 cellular levels were determined by Western blot analysis as described under Materials and Methods and $\beta$-actin was used as loading control

cells. However, in parallel experiments in RKO cells (Fig. 5c), DTT, GSH and NAC exhibited comparable activity as inhibitors of sulindac sulfide-induced downregulation of Sp1, Sp3 and $\mathrm{Sp} 4$ and the thiol antioxidants also inhibited the effects of sulindac sulfide on VEGF, bcl2 and survivin proteins in SW480 (Fig. 5d) and RKO (Fig. 5e) cells. In contrast, expression of pro-apoptotic protein Bax was decreased by sulindac sulfide (and reversed by antioxidants) in SW480 cells (Fig. 5d) but not in RKO cells (Fig. 5e). These results indicate that the effect of sulindac sulfide on Bax is cell context-dependent. In contrast, thiol antioxidants did not block the effects of sulindac sulfide on cyclin D1, suggesting cyclin D1 is regulated in an ROS/Sp-independent manner in SW480 and RKO cells. Previous studies with ROS inducers suggest that the mechanism of $\mathrm{Sp}$ downregulation is associated 


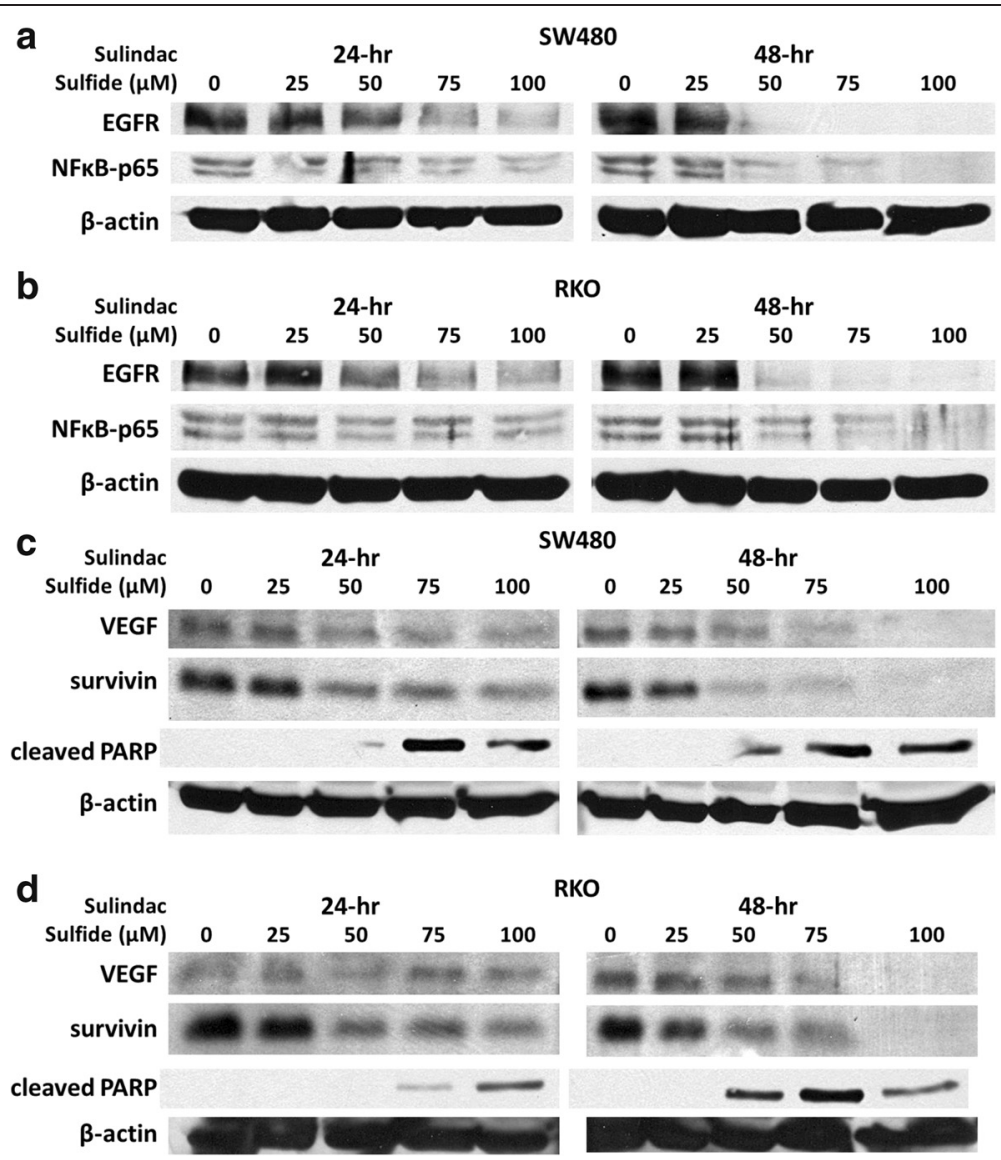

Fig. 3 Sulindac sulfide decreases expression of EGFR, p65, VEGF and survivin and induces PARP cleavage in colon cancer cells. a, b Sulindac sulfide decreases expression of EGFR and the p65 subunit of NFKB in SW480 and RKO cells. Cells were treated with DMSO, 25, 50, 75 and 100 $\mu \mathrm{M}$ sulindac sulfide for 24 and $48 \mathrm{~h}$. EGFR and p65 cellular levels were determined by Western blot analysis as described under Materials and Methods and $\beta$-actin was used as loading control. c, d Sulindac sulfide decreases expression of VEGF and survivin and induces PARP cleavage in SW480 and RKO cells. Cells were treated with DMSO, 25, 50,75 and $100 \mu \mathrm{M}$ sulindac sulfide for 24 and $48 \mathrm{~h}$. VEGF, survivin and cleaved PARP cellular levels were determined by Western blot analysis as described under Materials and Methods and $\beta$-actin was used as loading control

with ROS-dependent repression of microRNA-27a (miR27a) which results in the induction of the $\mathrm{Sp}$ repressor ZBTB10 [25, 40-42]. Treatment of SW480 and RKO cells with sulindac sulfide decreased both miR-27a promoter activity (Fig. 6a) and cellular level of miR-27a and this response was attenuated after cotreatment with antioxidant NAC (Fig. 6b). In a parallel experiment we observed that sulindac sulfide induced miR-27a-targeted ZBTB10 gene expression in SW480 and RKO cells (Fig. 6c). These results are consistent with previous studies in colon cancer cells showing that the miR-27a antagomir and ZBTB10 overexpression decrease expression of Sp1, Sp3 and Sp4 in RKO and SW480 cells [36]. Thus, like other ROSinducing anticancer agents [25, 40-42], sulindac sulfide disrupts the miR-27a:ZBTB10 axis and the transcriptional repressor ZBTB10 competitively binds GC-rich cis-element to decrease expression of Sp1, Sp3, Sp4 and Spregulated genes (Fig. 6d).

\section{Discussion}

Sp transcription factors Sp1, Sp3 and Sp4 are highly expressed in cancer cells/tumors and $\mathrm{Sp} 1$ is a negative prognostic factor for survival of gastric and pancreatic cancer and glioma patients [43-45]. Although Sp1 and other Sp proteins are important for early embryonic and postnatal development in mice, their expression is relatively low in adult tissues and there is evidence that Sp1 expression decreases with age in rodents and humans [46-48]. The functional importance of Sp1, $\mathrm{Sp} 3$ and Sp4 in cancer cells has been confirmed by RNA interference (RNAi) showing that knockdown of Sp transcription factors Sp1, Sp3 and Sp4 (singly or combined) decreases cell proliferation, survival, angiogenesis and inflammation [26, 35, 36, 42]. These results are consistent with identification (by RNAi) of several pro-oncogenic Sp-regulated genes important for cell growth (cyclin D1, EGFR, c-Met), survival (bcl-2, survivin), 


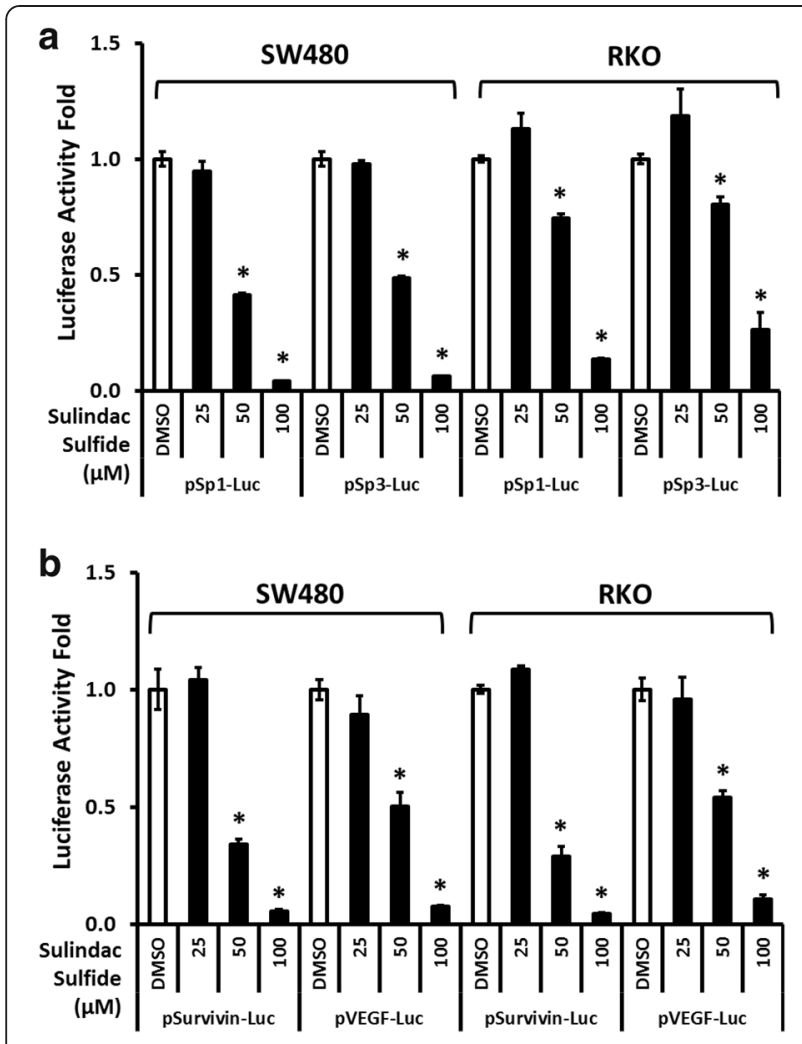

Fig. 4 Sulindac sulfide decreases promoter gene activity of Sp1, Sp3, survivin and VEGF in colon cancer cells. a Cells were transfected with promoter-luciferase reporter constructs containing -751 bp promoter sequence of SP1 gene (pSp1-Luc) or -417 bp of SP3 gene (pSp3-Luc). b Cells were transfected with constructs containing -269 bp of BIRC5 gene (pSurvivin-Luc) or -2018 bp of VEGFA gene (pVEGF-Luc). After $6 \mathrm{~h}$ of transfection, cells were treated with DMSO, 25, 50 and $100 \mu \mathrm{M}$ sulindac sulfide for $13 \mathrm{~h}$. Luciferase activity was determined as described under Materials and Methods. Experiments were done in triplicate and results are expressed as fold of control (mean \pm S.D.). Asterisk $\left(^{*}\right)$ indicates statistical difference between control (DMSO) and treatment $(P<0.05)$

angiogenesis (VEGF and VEGF receptors), and inflammation (p65 subunit of $\mathrm{NF \kappa B}$ ) [22, 23, 26, 41, 42]. Thus, Sp transcription factors clearly contribute to the transformed cell phenotype and represent an example of non-oncogene addiction by cancer cells. Studies in this laboratory show that several structurally-diverse anticancer drugs downregulate Sp transcription factors through two major pathways, namely, degradation (activation of proteasomes or caspases) or by ROS-dependent transcriptional repression (Fig. 6d) and activation of one or both pathways is dependent on the agent and cell context. For example, previous studies with NSAIDs show that tolfenamic acid induced proteasome-dependent degradation of Sp proteins in pancreatic cancer [38], the nitro-NSAID GT-094 induced ROS-dependent repression [25], and aspirin induced caspase-dependent degradation of $\mathrm{Sp} 1, \mathrm{Sp} 3$ and $\mathrm{Sp} 4$ in colon cancer cells and in a mouse xenograft [35].

In this study, we also observed that sulindac and its metabolites inhibited proliferation of SW480 and RKO colon cancer cells and sulindac sulfide was the most active compound (Figs. 1a, b, 2a and c) and this was consistent with their relatively potent growth-inhibitory effects observed in other studies [29, 30]. At concentrations of sulindac or sulindac sulfone that inhibited SW480 and RKO cell proliferation, the levels of Sp1, Sp3 or Sp4 proteins were unchanged (Fig. 1c and d), whereas sulindac sulfide-dependent growth inhibition was accompanied by decreased expression of Sp1, Sp3 and Sp4 (Fig. $2 \mathrm{~b}$ and d). These results clearly distinguish between sulindac sulfide and sulindac/sulindac sulfone and indicate that the anticancer activity of sulindac sulfide may be due, in part, to downregulation of Sp transcription factors.

Like tolfenamic acid and other compounds that induce Sp downregulation, sulindac sulfide also decreased expression of EGFR, survivin, VEGF and bcl-2 and also decreased the p65 subunit of NFKB which is Spregulated in only some cancer cell lines [26, 35, 37], and a previous study showed that high doses of sulindac also decreased survivin expression [49]. Tolfenamic acid induces proteasome-dependent downregulation of Sp1, Sp3 and Sp4 in pancreatic cancer cells [38]. However, proteasome inhibitors did not block sulindac sulfidemediated repression of these transcription factors.

Studies with several ROS-inducing anticancer agents show that ROS-dependent transcriptional repression of Sp1, Sp3 and Sp4 (and Sp-regulated genes) is due to downregulation of miR-27a and/or miR-20a/17-5p [25, 40-42]. Decreased expression of these microRNAs results in induction of miR-targeted ZBTB10 and/or ZBTB4, which have been characterized as "Sp-repressors" that competitively displace $\mathrm{Sp}$ transcription factors from GCrich promoter sites to decrease gene expression (Fig. 6d). In addition, similar results were observed in two cell lines (RKO and SW480) that have distinct genetic backgrounds, and previous studies in these cells with other agents that target Sp transcription factors also resulted in downregulation of $\mathrm{Sp}$ proteins $[25,35,36,40]$. In addition, pharmacologic doses of ascorbate (which induces $\mathrm{H}_{2} \mathrm{O}_{2}$ ), $t$ butylhydroperoxide and $\mathrm{H}_{2} \mathrm{O}_{2}$ also decreased expression of $\mathrm{Sp} 1, \mathrm{Sp} 3, \mathrm{Sp} 4$ and $\mathrm{Sp}$-regulated gene products in cancer cell lines $[26,50]$, and a number of other ROS-inducing agents including piperlongumine phenethylisothiocyanate and benzylisothiocyanate also downregulate Sp proteins [42].

In this study, sulindac sulfide was observed to induce ROS in SW480 and RKO cells in a time-dependent manner in flow cytometry experiments using an ROS indicator (Fig. 5). Results of our studies with sulindac sulfide are consistent with the ROS-dependent gene repression pathway where induction of ROS disrupts miR-27a- 


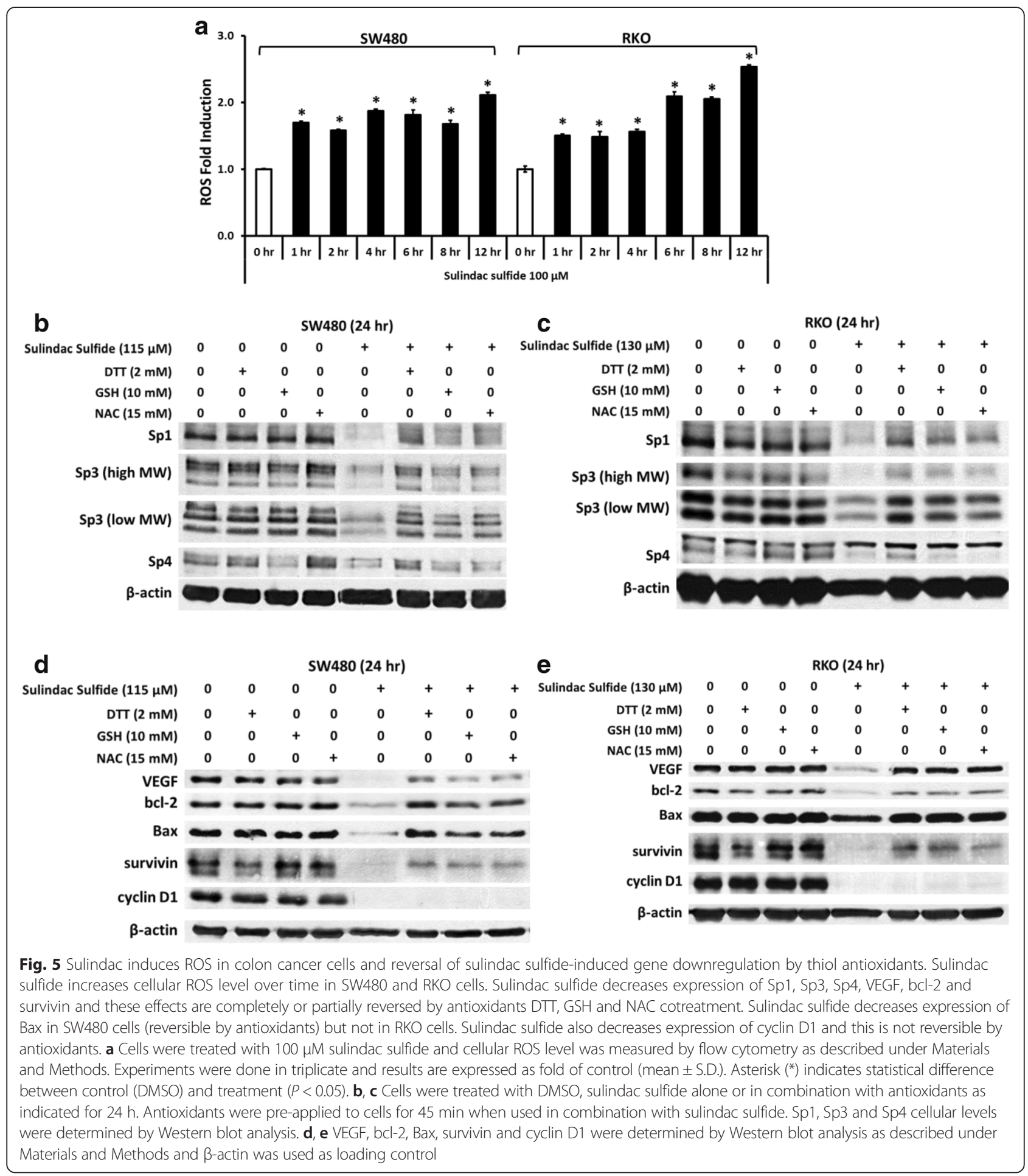

ZBTB10 interaction to decrease miR-27a and induce ZBTB10 (Fig. 6). ZBTB10 overexpression or miR-27a antagonism also decreases Sp protein expression $[36,51]$ and this is also consistent with sulindac sulfide-induced downregulation of Sp1, Sp3, Sp4 and Sp-regulated genes (Figs. 2 and 3).

\section{Conclusions}

This study demonstrates that sulindac sulfide, the active metabolite of sulindac which is known to exhibit antineoplastic activity in human and experimental models of colon cancer, also downregulates $\mathrm{Sp} 1, \mathrm{Sp} 3, \mathrm{Sp} 4$ and prooncogenic Sp-regulated genes in colon cancer cells. The 

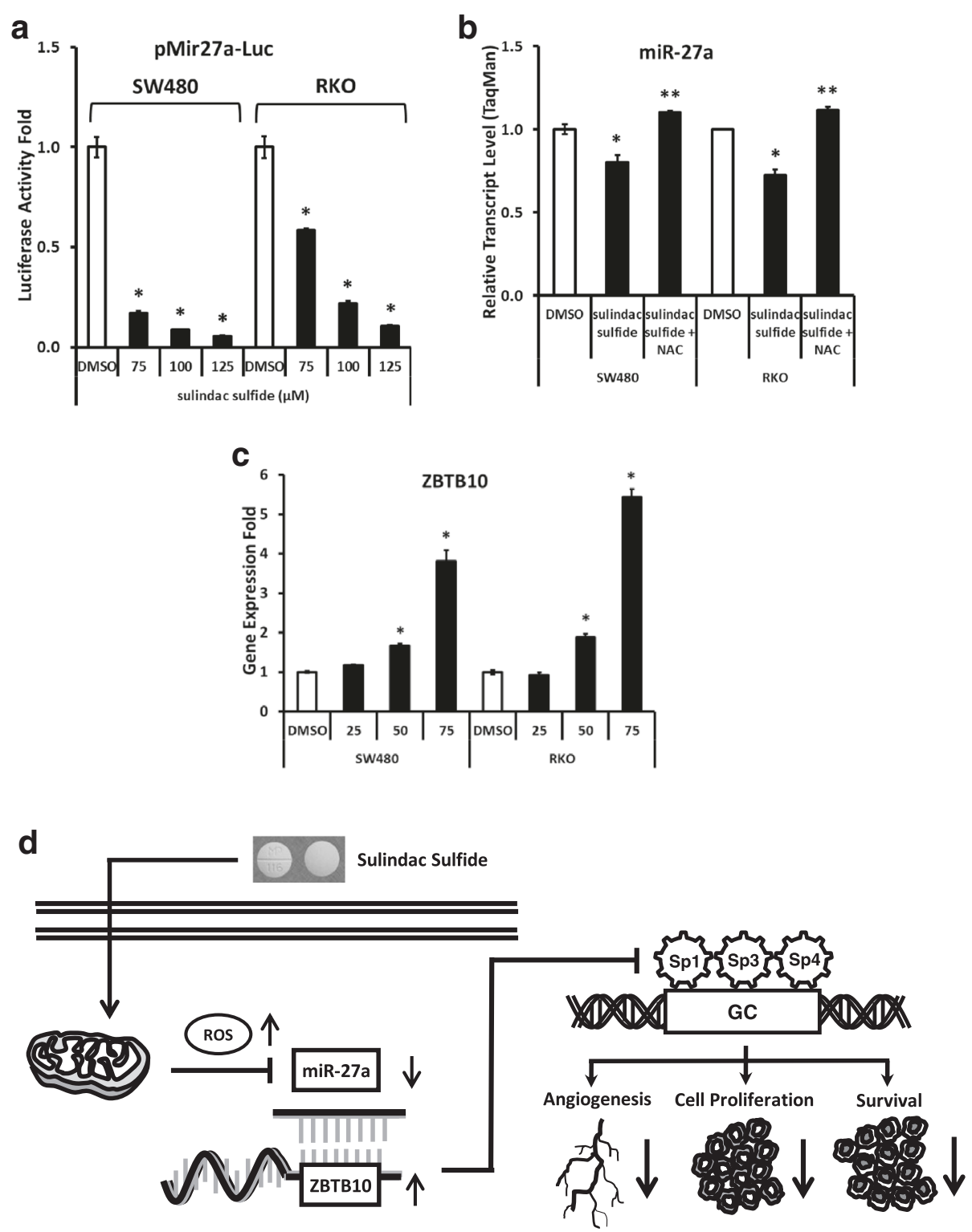

Fig. 6 Effects of sulindac sulfide on miR-27a and ZBTB10 in colon cancer cells. a Sulindac sulfide decreases miR-27a promoter activity in SW480 and RKO cells. Cells were transfected with luciferase construct containing -638 bp promoter sequence of miR-27a gene (pMir27a-Luc). After $6 \mathrm{~h}$ cells were treated with DMSO, 75, 100 and $125 \mu \mathrm{M}$ sulindac sulfide for $18 \mathrm{~h}$ and luciferase activity was determined as described under Materials and Methods. b Sulindac sulfide decreases miR-27a transcript level in SW480 and RKO cells and this effect is reversed by antioxidant NAC. Cells were treated with DMSO, $100 \mu \mathrm{M}$ sulindac sulfide alone or in combination with $10 \mathrm{mM} \mathrm{NAC}$ for $24 \mathrm{~h}$ and cellular level of the miR-27a transcript was determined by TaqMan PCR analysis as described under Materials and Methods. c Sulindac sulfide increases gene expression of ZBTB10 in SW480 and RKO cells. Cells were treated with DMSO, 25, 50 and $75 \mu \mathrm{M}$ sulindac sulfide for $24 \mathrm{~h}$ and ZBTB10 mRNA levels were determined by real-time PCR analysis as described under Materials and Methods. All experiments were done in triplicate and results are expressed as fold of control (mean \pm S.D.). Asterisk $\left(^{*}\right)$ indicates statistical difference between control (DMSO) and treatment, and double-asterisk $\left(^{*}\right.$ ) indicates statistical difference between single treatment and combination treatment $(P<0.05)$. $\mathbf{d}$ Effects of sulindac sulfide on the ROS-miR-27a-ZBTB10-Sp axis. Sulindac sulfide induces ROS; downregulates miR-27a; upregulates ZBTB10; downregulates Sp proteins and Sp-dependent survival/proliferative, inflammatory and angiogenic protein products; and induces growth inhibition and apoptosis

effects of sulindac sulfide also involve induction of ROS and the subsequent downregulation of miR-27a and induction of the "Sp repressor" ZBTB10, and this pathway has also been observed for other ROS inducers (Fig. 6d). It has previously been reported that high $\mathrm{Sp} 1 / \mathrm{Sp} 3$ binding to the urokinase receptor predicted poor survival of colon cancer patients [52] and high expression of Sp1 was associated with an increased depth of invasion in another set of colon cancer patients [53]. A previous study showed that sulindac sulfide induced apoptosis in HUVEC cells 
[54]; however, a higher concentration $(160 \mu \mathrm{M})$ was required, suggesting some specificity for cancer cell lines. Thus, the advantage/effectiveness of sulindac in colon cancer therapy may be due, in part, to the targeting of Sp transcription factors and it is possible that other anticancer agents or drug combinations that act, in part, through targeting Sp transcription factors may also be effective for colon cancer therapy.

\section{Abbreviations}

COX: Cyclooxygenase; DMEM: Dulbecco's modified Eagle's medium: DMSO: Dimethyl sulfoxide; DTT: Dithiothreitol; EGFR: Epidermal growth factor receptor; GSH: Glutathione; miR-27a: microRNA-27a; NAC: N-acetylcysteine; NSAIDs: Non-steroidal anti-inflammatory drugs; RNAi: RNA interference; ROS: Reactive oxygen species; Sp: Specificity protein; VEGF: Vascular endothelial growth factor.

\section{Competing interests}

The authors declare that they have no competing interests.

\section{Authors' contributions}

$\mathrm{XL}$ carried out some of the experimental procedures, performed the statistical analysis, reviewed initial draft of the manuscript. SSP carried out some of the experimental procedures. SS conceived of the study, participated in its design and coordination, wrote the initial draft of the manuscript. All authors have read and approved the final manuscript.

\section{Acknowledgements}

Funding was provided by the National Institute of Environmental Health Sciences (P30-ES023512), the Sid Kyle Endowment, and Texas AgriLife Research.

\section{Author details}

'Department of Veterinary Physiology \& Pharmacology, Texas A\&M University, College Station, TX 77843-4466, USA. ${ }^{2}$ Oklahoma Medical Research Foundation, 825 NE 13th St., Oklahoma City, OK 73104, USA.

Received: 7 July 2015 Accepted: 25 November 2015 Published online: 16 December 2015

\section{References}

1. Elwood PC, Gallagher AM, Duthie GG, Mur LA, Morgan G. Aspirin, salicylates, and cancer. Lancet. 2009;373(9671):1301-9.

2. Baron JA. Epidemiology of non-steroidal anti-inflammatory drugs and cancer. Prog Exp Tumor Res. 2003;37:1-24.

3. Jacobs EJ, Thun MJ, Bain EB, Rodriguez C, Henley SJ, Calle EE. A large cohort study of long-term daily use of adult-strength aspirin and cancer incidence. J Natl Cancer Inst. 2007;99(8):608-15.

4. Asano TK, McLeod RS. Nonsteroidal anti-inflammatory drugs and aspirin for the prevention of colorectal adenomas and cancer: a systematic review. Dis Colon Rectum. 2004:47(5):665-73.

5. Sandler RS, Halabi S, Baron JA, Budinger S, Paskett E, Keresztes R, et al. A randomized trial of aspirin to prevent colorectal adenomas in patients with previous colorectal cancer. N Engl J Med. 2003;348(10):883-90.

6. Baron JA, Cole BF, Sandler RS, Haile RW, Ahnen D, Bresalier R, et al. A randomized trial of aspirin to prevent colorectal adenomas. N Engl J Med. 2003;348(10):891-9.

7. Labayle D, Fischer D, Vielh P, Drouhin F, Pariente A, Bories C, et al. Sulindac causes regression of rectal polyps in familial adenomatous polyposis. Gastroenterology. 1991;101(3):635-9.

8. Giardiello FM, Hamilton SR, Krush AJ, Piantadosi S, Hylind LM, Celano P, et al. Treatment of colonic and rectal adenomas with sulindac in familial adenomatous polyposis. N Engl J Med. 1993;328(18):1313-6.

9. Matsumoto T, Nakamura S, Esaki M, Yao T, lida M. Effect of the non-steroidal anti-inflammatory drug sulindac on colorectal adenomas of uncolectomized familial adenomatous polyposis. J Gastroenterol Hepatol. 2006:21(1 Pt 2):251-7.

10. Scheper MA, Sauk JJ, Nikitakis NG. COX-independent antineoplastic effects of sulindac in oral cancer are mediated by survivin down-regulation. Anticancer Res. 2006;26(6B):4103-13.
11. Scheper MA, Nikitakis NG, Chaisuparat R, Montaner S, Sauk JJ. Sulindac induces apoptosis and inhibits tumor growth in vivo in head and neck squamous cell carcinoma. Neoplasia (New York, NY). 2007;9(3):192-9.

12. Scheper MA, Nikitakis NG, Sauk JJ. Survivin is a downstream target and effector of sulindac-sensitive oncogenic Stat3 signalling in head and neck cancer. Int J Oral Maxillofac Surg. 2007;36(7):632-9.

13. Zhang T, Fields JZ, Ehrlich SM, Boman BM. The chemopreventive agent sulindac attenuates expression of the antiapoptotic protein survivin in colorectal carcinoma cells. J Pharmacol Exp Ther. 2004;308(2):434-7.

14. Seo SK, Lee HC, Woo SH, Jin HO, Yoo DH, Lee SJ, et al. Sulindac-derived reactive oxygen species induce apoptosis of human multiple myeloma cells via p38 mitogen activated protein kinase-induced mitochondrial dysfunction. Apoptosis. 2007;12(1):195-209.

15. Rice PL, Kelloff J, Sullivan H, Driggers LJ, Beard KS, Kuwada S, et al. Sulindac metabolites induce caspase- and proteasome-dependent degradation of beta-catenin protein in human colon cancer cells. Mol Cancer Ther. 2003; 2(9):885-92.

16. Li H, Liu L, David ML, Whitehead CM, Chen M, Fetter JR, et al. Pro-apoptotic actions of exisulind and CP461 in SW480 colon tumor cells involve beta-catenin and cyclin D1 down-regulation. Biochem Pharmacol. 2002:64(9):1325-36.

17. Han A, Song Z, Tong C, Hu D, Bi X, Augenlicht LH, et al. Sulindac suppresses beta-catenin expression in human cancer cells. Eur J Pharmacol. 2008;583(1):26-31.

18. Pangburn HA, Kraus H, Ahnen DJ, Rice PL. Sulindac metabolites inhibit epidermal growth factor receptor activation and expression. Journal of carcinogenesis. 2005;4:16

19. Pangburn HA, Ahnen DJ, Rice PL. Sulindac metabolites induce proteosomal and lysosomal degradation of the epidermal growth factor receptor. Cancer Prev Res (Phila). 2010;3(4):560-72.

20. Pyriochou A, Tsigkos S, Vassilakopoulos T, Cottin T, Zhou Z, Gourzoulidou E, et al. Anti-angiogenic properties of a sulindac analogue. Br J Pharmacol. 2007;152(8):1207-14

21. Vaish V, Sanyal SN. Role of Sulindac and Celecoxib in the regulation of angiogenesis during the early neoplasm of colon: exploring PI3-K/PTEN/Akt pathway to the canonical Wnt/beta-catenin signaling. Biomed Pharmacother. 2012;66(5):354-67.

22. Chintharlapalli S, Papineni S, Ramaiah SK, Safe S. Betulinic acid inhibits prostate cancer growth through inhibition of specificity protein transcription factors. Cancer Res. 2007:67(6):2816-23.

23. Chadalapaka G, Jutooru I, Burghardt R, Safe S. Drugs that target specificity proteins downregulate epidermal growth factor receptor in bladder cancer cells. Molecular cancer research : MCR. 2010;8(5):739-50.

24. Abdelrahim M, Safe S. Cyclooxygenase-2 inhibitors decrease vascular endothelial growth factor expression in colon cancer cells by enhanced degradation of Sp1 and Sp4 proteins. Mol Pharmacol. 2005;68(2):317-29.

25. Pathi SS, Jutooru I, Chadalapaka G, Sreevalsan S, Anand S, Thatcher GR, et al GT-094, a NO-NSAID, inhibits colon cancer cell growth by activation of a reactive oxygen species-microRNA-27a: ZBTB10-specificity protein pathway. Molecular cancer research : MCR. 2011;9(2):195-202.

26. Jutooru I, Chadalapaka G, Lei P, Safe S. Inhibition of NFkappaB and pancreatic cancer cell and tumor growth by curcumin is dependent on specificity protein down-regulation. J Biol Chem. 2010;285(33):25332-44.

27. Safe S, Imanirad P, Sreevalsan S, Nair V, Jutooru I. Transcription factor Sp1, also known as specificity protein 1 as a therapeutic target. Expert Opin Ther Targets. 2014;18(7):759-69.

28. Nicolas M, Noe V, Jensen KB, Ciudad CJ. Cloning and characterization of the $5^{\prime}$-flanking region of the human transcription factor Sp1 gene. J Biol Chem. 2001;276(25):22126-32

29. Tapias A, Monasterio P, Ciudad CJ, Noe V. Characterization of the 5'-flanking region of the human transcription factor $\mathrm{Sp3}$ gene. Biochim Biophys Acta. 2005:1730(2):126-36.

30. Finkenzeller G, Sparacio A, Technau A, Marme D, Siemeister G. Sp1 recognition sites in the proximal promoter of the human vascular endothelial growth factor gene are essential for platelet-derived growth factor-induced gene expression. Oncogene. 1997:15(6):669-76.

31. Zhu N, Gu L, Findley HW, Chen C, Dong JT, Yang L, et al. KLF5 Interacts with p53 in regulating survivin expression in acute lymphoblastic leukemia. J Biol Chem. 2006;281(21):14711-8

32. Lee $\mathrm{Y}, \mathrm{Kim} \mathrm{M}$, Han J, Yeom KH, Lee $\mathrm{S}$, Baek SH, et al. MicroRNA genes are transcribed by RNA polymerase II. EMBO J. 2004;23(20):4051-60. 
33. Piazza GA, Rahm AK, Finn TS, Fryer BH, Li H, Stoumen AL, et al. Apoptosis primarily accounts for the growth-inhibitory properties of sulindac metabolites and involves a mechanism that is independent of cyclooxygenase inhibition, cell cycle arrest, and p53 induction. Cancer Res. 1997;57(12):2452-9.

34. Bock JM, Menon SG, Goswami PC, Sinclair LL, Bedford NS, Jackson RE, et al. Differential activity of sulindac metabolites against squamous cell carcinoma of the head and neck is mediated by p21waf1/cip1 induction and cell cycle inhibition. Cancer Biol Ther. 2007;6(1):30-9.

35. Pathi S, Jutooru I, Chadalapaka G, Nair V, Lee SO, Safe S. Aspirin inhibits colon cancer cell and tumor growth and downregulates specificity protein (Sp) transcription factors. PLoS One. 2012;7(10):e48208.

36. Chintharlapalli S, Papineni S, Abdelrahim M, Abudayyeh A, Jutooru I, Chadalapaka G, et al. Oncogenic microRNA-27a is a target for anticancer agent methyl 2-cyano-3,11-dioxo-18beta-olean-1,12-dien-30-oate in colon cancer cells. International journal of cancer Journal international du cancer. 2009;125(8):1965-74

37. Pathi S, Li X, Safe S. Tolfenamic acid inhibits colon cancer cell and tumor growth and induces degradation of specificity protein (Sp) transcription factors. Mol Carcinog. 2014;53 Suppl 1:E53-61.

38. Abdelrahim M, Baker $\mathrm{CH}$, Abbruzzese JL, Safe S. Tolfenamic acid and pancreatic cancer growth, angiogenesis, and Sp protein degradation. J Natl Cancer Inst. 2006;98(12):855-68.

39. Chadalapaka G, Jutooru I, Chintharlapalli S, Papineni S, Smith 3rd R, Li X, et al. Curcumin decreases specificity protein expression in bladder cancer cells. Cancer Res. 2008;68(13):5345-54.

40. Gandhy SU, Kim K, Larsen L, Rosengren RJ, Safe S. Curcumin and synthetic analogs induce reactive oxygen species and decreases specificity protein (Sp) transcription factors by targeting microRNAs. BMC Cancer. 2012;12:564.

41. Chadalapaka G, Jutooru I, Safe S. Celastrol decreases specificity proteins (Sp) and fibroblast growth factor receptor-3 (FGFR3) in bladder cancer cells. Carcinogenesis. 2012;33(4):886-94

42. Jutooru I, Guthrie AS, Chadalapaka G, Pathi S, Kim K, Burghardt R, et al. Mechanism of action of phenethylisothiocyanate and other reactive oxygen species-inducing anticancer agents. Mol Cell Biol. 2014;34(13): 2382-95.

43. Yao JC, Wang L, Wei D, Gong W, Hassan M, Wu TT, et al. Association between expression of transcription factor Sp1 and increased vascular endothelial growth factor expression, advanced stage, and poor survival in patients with resected gastric cancer. Clin Cancer Res. 2004;10(12 Pt 1):4109-17.

44. Jiang NY, Woda BA, Banner BF, Whalen GF, Dresser KA, Lu D. Sp1, a new biomarker that identifies a subset of aggressive pancreatic ductal adenocarcinoma. Cancer Epidemiol Biomarkers Prev. 2008;17(7):1648-52.

45. Guan H, Cai J, Zhang N, Wu J, Yuan J, Li J, et al. Sp1 is upregulated in human glioma, promotes MMP-2-mediated cell invasion and predicts poor clinical outcome. Int J Cancer. 2012;130(3):593-601.

46. Ammendola R, Mesuraca M, Russo T, Cimino F. Sp1 DNA binding efficiency is highly reduced in nuclear extracts from aged rat tissues. J Biol Chem. 1992;267(25):17944-8.

47. Adrian GS, Seto E, Fischbach KS, Rivera EV, Adrian EK, Herbert DC, et al. YY1 and Sp1 transcription factors bind the human transferrin gene in an agerelated manner. J Gerontol A Biol Sci Med Sci. 1996;51(1):B66-75.

48. Oh JE, Han JA, Hwang ES. Downregulation of transcription factor, Sp1, during cellular senescence. Biochem Biophys Res Commun. 2007;353(1):86-91.

49. lizaka M, Furukawa Y, Tsunoda T, Akashi H, Ogawa M, Nakamura Y Expression profile analysis of colon cancer cells in response to sulindac or aspirin. Biochem Biophys Res Commun. 2002;292(2):498-512.

50. Pathi SS, Lei P, Sreevalsan S, Chadalapaka G, Jutooru I, Safe S. Pharmacologic doses of ascorbic acid repress specificity protein (Sp) transcription factors and Sp-regulated genes in colon cancer cells. Nutr Cancer. 2011;63(7):1133-42.

51. Mertens-Talcott SU, Chintharlapalli S, Li X, Safe S. The oncogenic microRNA27 a targets genes that regulate specificity protein transcription factors and the G2-M checkpoint in MDA-MB-231 breast cancer cells. Cancer Res. 2007; 67(22):11001-11.

52. Maurer GD, Leupold JH, Schewe DM, Biller T, Kates RE, Hornung HM, et al. Analysis of specific transcriptional regulators as early predictors of independent prognostic relevance in resected colorectal cancer. Clin Cancer Res. 2007:13(4):1123-32.
53. Wang F, Ma YL, Zhang P, Shen TY, Shi CZ, Yang YZ, et al. SP1 mediates the link between methylation of the tumour suppressor miR-149 and outcome in colorectal cancer. J Pathol. 2013;229(1):12-24.

54. Liou JY, Wu CC, Chen BR, Yen LB, Wu KK. Nonsteroidal anti-inflammatory drugs induced endothelial apoptosis by perturbing peroxisome proliferatoractivated receptor-delta transcriptional pathway. Mol Pharmacol. 2008;74(5): 1399-406.

\section{Submit your next manuscript to BioMed Central and we will help you at every step:}

- We accept pre-submission inquiries

- Our selector tool helps you to find the most relevant journal

- We provide round the clock customer support

- Convenient online submission

- Thorough peer review

- Inclusion in PubMed and all major indexing services

- Maximum visibility for your research

Submit your manuscript at www.biomedcentral.com/submit 